\title{
Cosmetic wastewater treatment using dissolved air flotation
}

\author{
Jan Paweł Bogacki, Piotr Marcinowski, Jeremi Naumczyk, Piotr Wiliński \\ Warsaw University of Technology, Poland \\ Faculty of Building Services, Hydro and Enviromnental Engineering \\ *Corresponding author's e-mail: jan.bogacki@is.pw.edu.pl
}

\begin{abstract}
Keywords: wastewater treatment, GC-MS, gas chromatography, cosmetic wastewater, dissolved air flotation, PPCPs.

Abstract: Five cosmetics wastewater samples were treated by Dissolved Air Flotation (DAF) assisted by coagulation. Different aluminum based coagulants were used: $\left(\mathrm{Al}_{2}\left(\mathrm{SO}_{4}\right)_{3}, \mathrm{Al} 1019, \mathrm{Al} 3010, \mathrm{Al} 3030, \mathrm{Al} 3035\right.$, PAX 16 and PAX 19). The raw wastewater COD values were in the range $285-2124 \mathrm{mg} / \mathrm{l}$. The efficiency of DAF depended on different coagulants and production profile of factory. COD removal was varied from 11.1 to $77.7 \%$. The efficiency of coagulants was similar during treatment of particular sample. The best results were obtained with $\mathrm{Al}_{2}\left(\mathrm{SO}_{4}\right)_{3}$ and for sample 5 - lotions and shampoos production. The wastewater from UV filter creams production (sample 4) was resistant to treatment by DAF regardless of used coagulant. HS-SPME-GC-MS analysis can be a confirmation of DAF effectiveness.
\end{abstract}

\section{Introduction}

The main reason for the considerable differentiation in the composition and concentration of pollutants in cosmetic wastewater is the variance in the amounts and types of produced cosmetics by individual manufacturers and season. Larger cosmetic factories, that produce a wider group of products, are more representative of the type of cosmetic wastewater generated. The most common and least expensive method used for wastewater treatment is biological treatment (Burek 2008, Friha et al. 2012), but also chemical methods are used. (Burek 2008, Wang et al. 2008, de Melo et al. 2013, Vlyssides et al. 2009).

Due to the increase in the restrictions of discharge limits for treated wastewater, new and prospective methods of treatment are currently being evaluated. These treatments must fulfill the discharge requirements with low investment and operating costs at the same time. Among analyzed solutions, such physicochemical and chemical methods were used: coagulation coupled with sedimentation (Aloui et al. 2009, El-Gohary et al. 2010, Perdigon-Melon et al. 2010, Naumczyk et al. 2013, Naumczyk et al. 2014, Carpinteyro-Urban et al. 2012, coagulation coupled with dissolved air flotation (DAF) (El-Gohary et al. 2010), electrocoagulation (Aloui et al. 2009, (Boroski et al. 2009), advanced oxidation processes (AOPs) (Wang et al. 2008, Aloui et al. 2009, Perdigon-Melon et al. 2010, Naumczyk et al. 2014, Boroski et al. 2009, Bautista et al. 2007, Bautista et al. 2010a, Bautista et al. 2010b, Carballa et al. 2007, Marcinowski et al. 2014, Ebraheim et al. 2013). Advanced biological methods were also proposed: membrane reactors (Friha et al. 2012, Friha et al. 2104, Monsalvo et al.
2014), mixed anaerobic-aerobic processes (Zhang et al. 2013) or anaerobic reactors (Puyol et al. 2011).

The major advantage of DAF over the previously described process is the ability to treat more wastewater. The DAF process is very fast. The time required for the coagulation, flocculation and mixture saturation is very brief and is completed within a few minutes. Furthermore, the time required for the efficient separation of the resulting precipitate from the treated effluent is very short when compared to coagulation coupled with sedimentation. DAF also requires less area for treatment facility. The entire DAF process installation can fit in a room with a capacity of $100 \mathrm{~m}^{3}$. Installations for both the biological treatment, as well as other chemical and physico-chemical methods occupy much larger space. Cosmetic factories are usually located on relatively small plots of land with a limited amount of space available for the wastewater treatment installation. This is one of the main advantages that DAF offers as the primary means of cosmetic wastewater treatment. Because of the large variability of physico-chemical properties and the presence of substances resistant to biodegradation causes in cosmetic wastewater, it is not possible to use biological methods in the treatment. DAF consists of a transfer of compounds that are removed from liquid phase into solid (sludge) phase. Additionally, cosmetic wastewater typically contains a substantial content of oils with natural tendency to spontaneous flotation. This makes the DAF process extremely effective in comparison with other methods. The sludge created as a result of the DAF process requires further processing, including dewatering and then burning or deposition in a landfill. However, there are similar drawbacks in alternative treatment methods, such as biological treatment 
or coagulation coupled with sedimentation. It should be noted, however, that the precipitate resulting from DAF is usually less hydrated and more easily processed than, for example, sludge obtained as a result of coagulation coupled with sedimentation.

The aim of this study was to provide further information and expand the knowledge of cosmetic wastewater treatment using the DAF method; and to examine the efficiency and definition of optimal cosmetic wastewater treatment conditions. The removal of pollutants must conform with discharge limits and allow for effective biological treatment in municipal wastewater treatment plants. The efficiency of the process was assessed by changes in COD and the results of HS-SPME-GC-MS analyses.

\section{Materials and methods}

Wastewater samples were collected between September 2011 and February 2012 from the compensation reservoir in a cosmetic factory. This facility manufactured a wide range of cosmetics including: lipsticks, serum, creams, and UV filters. After collection, the wastewater samples were refrigerated at $4^{\circ} \mathrm{C}$ until the analysis.

The following parameters were determined according to EN or ISO Standards in the raw wastewater after stirring: $\mathrm{COD}, \mathrm{COD}_{\text {dis }}$ (for sample filtered with $0.45 \mu \mathrm{m}$ filter) (ISO 6060), total suspended solids (TSS) (EN 872), pH (EN ISO 10523), turbidity (EN ISO 7027), specific conductivity (EN 27888), alkalinity (ISO 740), and anionic surfactants (EN 903), calcium - ISO 6058, ammonium nitrogen - ISO 5664, nitrate nitrogen - EN ISO 13395, phosphates - ISO 6878, sulfates - ISO 9280, chlorides - ISO 9297.

Petroleum ether extractable organics (PEEO) were gravimetrically determined by extraction of $500 \mathrm{ml}$ sample with petroleum ether $(50+50 \mathrm{ml})$.

Stirred wastewater samples were left for $30 \mathrm{~min}$ for sedimentation and subsequent removal of easily settleable solids (ESS). The kinetics of ESS settling was measured. All studies concerning the treatment of decanted wastewater were carried out within $72 \mathrm{~h}$ after collection of samples.

Wastewater after sedimentation was treated using a laboratory DAF unit. The following coagulant solutions were used in the studies: $\mathrm{Al}_{2}\left(\mathrm{SO}_{4}\right)_{3}$ with the concentration of $50 \mathrm{mg} / \mathrm{ml} \mathrm{Al}^{3+}$, Brenntag Al 1019, Al 3010, Al 3030, Al 3035 prehydrolysed coagulants containing aluminum salts and Kemipol PAX16 and PAX19 coagulants containing aluminum salts. Parameters of coagulants are shown in Table 1. The effect of coagulants was aided by anionic flocculant Flopam
AN913SH that was prepared as aqueous stock solution $1 \mathrm{ml}$ $=0.5 \mathrm{mg}$.

The experiments were carried out with 1L sample. After the addition of coagulants, the $\mathrm{pH}$ correction to 7.0 was made, with $1 \mathrm{M} \mathrm{HCl}$ or $3 \mathrm{M} \mathrm{NaOH}$. The $\mathrm{pH} 7.0$ was considered as optimal in initial experiments. Reagents were added during fast stirring ( $5 \mathrm{~min}$ ), and afterwards $12 \mathrm{mg} / \mathrm{l}$ (the dose was set during the initial experiments) of flocculant was dosed during slow stirring $(30 \mathrm{~s})$. After flocculation was observed, the wastewater was transferred into the laboratory DAF unit of $1 \mathrm{~L}$ capacity (total volume sample + air $1.4 \mathrm{~L}$ ), where it was saturated with air under 6 bars pressure. Afterwards, the flotation cell was gently stirred and placed in horizontal position to obtain the highest phase exchange area (between gas-liquid phases). After 5 min retention, the flotation cell was emptied with a constant pressure of 6 bars. Wastewater was then transferred to the separation reactor in which the treated wastewater was separated from the sludge under pressure lowered to atmospheric pressure.

After wastewater was transferred to a separation reactor, complete separation of created precipitate from the treated effluent was achieved after 2 min of flotation. Samples for determination of COD were taken 3 min after the completion of the flotation process. The amount of air introduced into the wastewater was estimated on the basis of Wang (Wang et al. 2010). The estimated value is about $133 \mathrm{mg} / \mathrm{l}$ ( $\mathrm{mg}$ of air per $1 \mathrm{~L}$ of sample), assuming $100 \%$ efficiency of mass transfer.

Afterwards, the separation treated wastewater parameters and the volume of generated sludge were measured. The experiments were made in room temperature (ca. $20^{\circ} \mathrm{C}$ ). The layout of the laboratory DAF unit for treatment process is presented in Figure 1.

The identification and quantitative analyses of the organic components in raw wastewater samples and after dissolved air flotation were performed using Head Space, Solid-Phase MicroExtraction, Gas Chromatography - Mass Spectrometry (HS-SPME-GC-MS). $10 \mathrm{ml}$ of the sample was placed into $40 \mathrm{ml}$ amber glass vials with $2.5 \mathrm{~mm}$ Butyl red/PTFE septum (Supelco). Microsorption was performed at $75^{\circ} \mathrm{C}$ for $15 \mathrm{~min}$ with Supelco PDMS $100 \mu \mathrm{m}$ fiber. Desorption was performed in a chromatograph injector at $280^{\circ} \mathrm{C}$ for $2 \mathrm{~min}$. The analysis was performed with a Finnigan GCQ chromatograph with a Restek RTX-5MS and $30 \mathrm{~m}, 0.25 \mathrm{~mm}$ and $0.25 \mu \mathrm{m}$ columns. The following temperature program was applied: $50^{\circ} \mathrm{C}$ for $2 \mathrm{~min}$ and $5^{\circ} \mathrm{C} / \mathrm{min}$ up to $300^{\circ} \mathrm{C}$ before maintaining at $300^{\circ} \mathrm{C}$ for $10 \mathrm{~min}$. A mass spectrometer was used as a detector in the ionization mode $\mathrm{EI}$, at $70 \mathrm{eV}$ and $185^{\circ} \mathrm{C}$ across a range of 50

Table 1. Parameters of coagulants [www.brenntag.pl, www.kemipol.com]

\begin{tabular}{|l|c|c|c|c|c|c|}
\hline \multicolumn{1}{|c|}{ Parameter } & Al 3010 & Al 1019 & Al 3030 & Al 3035 & PAX 16 & PAX 19 \\
\hline $\mathrm{Al}_{2} \mathrm{O}_{3}[\%]$ & $>18.9$ & $23.0-24.2$ & $>17.01$ & $>17.0$ & $15.5 \pm 0.4$ & $16.0 \pm 0.9$ \\
\hline $\mathrm{Al}^{3+}[\%]$ & $>10.0$ & $12.2-12.8$ & $>9.0$ & $>9.0$ & $8.2 \pm 0.2$ & $8.5 \pm 0.3$ \\
\hline $\mathrm{Al}^{3+}[\mathrm{mg} / \mathrm{l}]$ & $>126$ & $159.8-177.9$ & $>108$ & $>108$ & $100-107.5$ & $99.6-105.4$ \\
\hline Chlorides [\%] & $<6.5$ & $7.0-11.0$ & $<6.0$ & $<6.0$ & $8 \pm 2$ & $5.5 \pm 0.5$ \\
\hline Density kg/m ${ }^{3}$ & $<1260$ & $1310-1390$ & 1200 & $1150-1250$ & $1250-1280$ & $1220 \pm 20$ \\
\hline $\mathrm{pH}$ & $>4.1$ & $3.1-3.9$ & 3.8 & 3.7 & $<1$ & $4.0 \pm 0.5$ \\
\hline Alkalinity [mval/l] & $>70$ & $80-90$ & $>70$ & $>90$ & $<40$ & $85 \pm 5$ \\
\hline
\end{tabular}




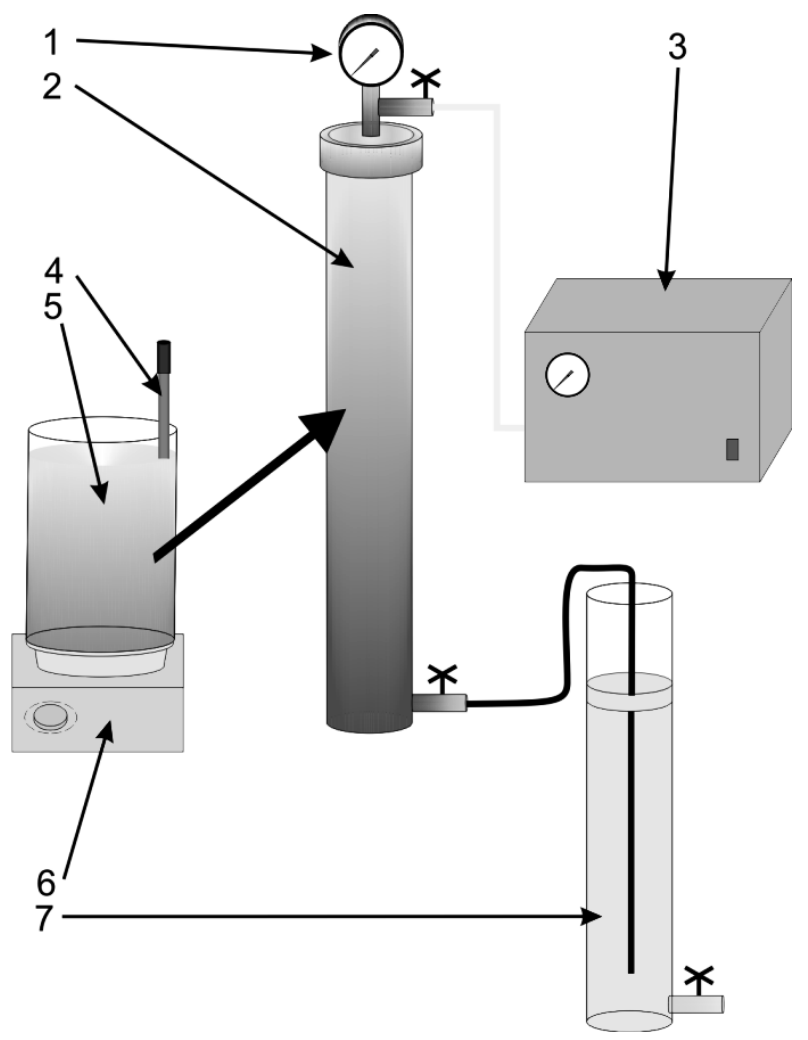

Fig. 1. Dissolved air flotation experimental set up: 1 - manometer, 2 - DAF unit, 3 - compressor, 4 - pH-meter, 5 - reactor, 6 - magnetic stirrer, 7 - separation reactor

to $650 \mathrm{amu}$. Mass spectra were compared to the NIST 98.L published spectra. Xcalibur Qual Browser v.1.2 was used for data acquisition and handling.

\section{Results and Discussion}

\section{Characteristics of raw wastewater}

The raw wastewater parameters are shown in Table 2. This wastewater was generated during the production of body creams, nail creams, creams with UV filters, rejuvenation serum with UV filters and antioxidants and shampoos.

The composition of pollutants varied in the collected samples. The COD value for this wastewater was in range 758-2124 mg/l. The lowest COD values were observed in samples 1 and 2 (285 and $314 \mathrm{mg} / \mathrm{l}$, respectively). The wastewater from powders production (sample 1) had a small quantity of pollutants. Whereas sample 2 was widely different from sample 1 despite similar COD values. The main pollutants in sample 2 from bath salts production were dissociated inorganic salts (conductivity $9100 \mu \mathrm{S} / \mathrm{cm}$ ) and mineral suspension (TSS $142 \mathrm{mg} / \mathrm{l})$. Other samples (3, 4 and 5) had higher pollutants loads. This wastewater was generated during production of body creams, nail creams, creams with UV filters, rejuvenation serum with UV filters and antioxidants, and shampoos. The highest values of COD, BOD, PEEO, TSS and turbidity were observed in samples 3 and 5 . The suspended solids content in the overall pollutants loading was similar in all samples and varied from $66.0 \%$ (in sample 5) up to $78.2 \%$ (in sample 3 ). In cosmetic wastewater, part of the pollutants loading was in the form of suspended solids and partially in soluble form. $\mathrm{COD}_{\text {dis }}$ was in all cases significantly lower than for raw wastewater. The marginal presence of easy settleable solids $(<0.5 \mathrm{ml} / \mathrm{l})$ was related to residuals of produced cosmetics which were not separated in compensation reservoir (also function of settling tank for ESS). All samples contained small amount of anionic surfactants, lower than $20 \mathrm{mg} / \mathrm{l}$. The color of the wastewater changed frequently what can be explained by the presence of colorants in cosmetics. When there is no production of "colorful" products (i.e. powders or eyeliners) wastewater color is milky-grey. However, when cosmetics with colorants were produced, the wastewater had different color: orange, blue or black.

The biological treatment of the discussed wastewater without previous pretreatment would have given unsatisfactory results due to low $\mathrm{BOD}_{5} / \mathrm{COD}$ ratio, which varied from 0.04 to 0.1 . The possible explanation of low $\mathrm{BOD}_{5} / \mathrm{COD}$ ratio is the presence of chemical substances resistant to biochemical decomposition or possible toxic substances for microorganisms of activated sludge.

\section{Dissolved Air Flotation}

The efficiency of DAF for sample 1 is shown in Table 3.

The flotation efficiency for sample 1 varied with respect to COD removal and was dependent on the amount of used coagulant. The range of efficiency was from 33.7 to $70.2 \%$ (COD after treatment $85-189 \mathrm{mg} / \mathrm{l}$ ). The highest removal of COD was observed with Al 3035 and the lowest with Al 1019. The sludge floated with use of PAX 16 and PAX 19 was characterized as not stable. Sludge agglomerates were destroyed even while floating on the surface. This caused partial sedimentation of the sludge and partial suspension of 
Table 2. Raw wastewater characteristics

\begin{tabular}{|c|c|c|c|c|c|c|}
\hline \multirow{2}{*}{ Parameter } & \multirow{2}{*}{ Unit } & \multicolumn{5}{|c|}{ Sample no } \\
\hline & & 1 & 2 & $3^{*}$ & $4^{*}$ & $5^{*}$ \\
\hline $\begin{array}{l}\text { Production } \\
\text { profile }\end{array}$ & - & powders & bath salts & $\begin{array}{c}\text { serum } \\
\text { with antioxidants }\end{array}$ & $\begin{array}{c}\text { creams } \\
\text { with UV filters }\end{array}$ & $\begin{array}{l}\text { body creams } \\
\text { and shampoos }\end{array}$ \\
\hline COD & mg/l & 285 & 314 & 1507 & 758 & 2124 \\
\hline$C O D_{\text {dis }}$ & $\mathrm{mg} / \mathrm{l}$ & 221 & 242 & 1179 & 527 & 1402 \\
\hline $\mathrm{BOD}_{5}$ & mg/l & 24 & 12 & 150 & 48 & 168 \\
\hline $\mathrm{BOD}_{5} / \mathrm{COD}$ & - & 0.08 & 0.04 & 0.10 & 0.06 & 0.08 \\
\hline PEEO & mg/l & 0.8 & 1.1 & 58 & 137 & 258 \\
\hline Surfactants & $\mathrm{mg} / \mathrm{l}$ & 10 & 15 & 20 & 15 & 20 \\
\hline TSS & $\mathrm{mg} / \mathrm{l}$ & 20 & 142 & 811 & 129 & 584 \\
\hline ESS & $\mathrm{ml} / \mathrm{l}$ & $<0.5$ & $<0.5$ & $<0.5$ & $<0.5$ & $<0.5$ \\
\hline $\mathrm{pH}$ & - & 7.45 & 7.85 & 7.90 & 9.10 & 7.40 \\
\hline Conductivity & $\mu \mathrm{S} / \mathrm{cm}$ & 1259 & 9100 & 1265 & 1042 & 2640 \\
\hline Turbidity & NTU & 80 & 100 & 150 & 70 & 800 \\
\hline Alkalinity & $\mathrm{mval} / \mathrm{l}$ & 4.5 & 5.1 & 7.6 & 5.3 & 3.2 \\
\hline $\mathrm{Cl}^{-}$ & $\mathrm{mg} / \mathrm{l}$ & 172 & 190 & 122 & 82 & 742 \\
\hline $\mathrm{PO}_{4}^{3-}$ & $\mathrm{mg} / \mathrm{l}$ & nd & nd & 2 & 4 & 5 \\
\hline $\mathrm{NO}_{3}^{-}$ & $\mathrm{mg} / \mathrm{l}$ & nd & nd & 2.5 & 2 & 3 \\
\hline $\mathrm{NH}_{4}^{+}$ & $\mathrm{mg} / \mathrm{l}$ & 4 & 3.5 & 12.5 & 2 & 2.5 \\
\hline $\mathrm{Ca}^{2+}$ & $\mathrm{mg} / \mathrm{l}$ & 71 & 80 & 84 & 51 & 170 \\
\hline $\mathrm{Mg}^{2+}$ & $\mathrm{mg} / \mathrm{l}$ & 17 & 20 & 24 & 15 & 36 \\
\hline
\end{tabular}

nd - not detected, * (Naumczyk et al. 2014)

Table 3. COD value after the Dissolved Air Flotation in the sample 1

\begin{tabular}{|l|c|c|c|c|c|c|c|}
\hline \multicolumn{1}{|c|}{ Coagulant } & $\mathbf{A l}_{2}\left(\mathbf{S O}_{4}\right)_{3}$ & $\mathbf{A l ~ 3 0 1 0}$ & $\mathbf{A l ~ 1 0 1 9}$ & $\mathbf{A l ~ 3 0 3 0}$ & $\mathbf{A l ~ 3 0 3 5}$ & PAX 16 & PAX 19 \\
\hline COD [mg/l] & 136 & 122 & 189 & 108 & 85 & 170 & 170 \\
\hline COD removal [\%] & 52.3 & 57.2 & 33.7 & 62.1 & 70.2 & 40.4 & 40.4 \\
\hline $\begin{array}{l}\text { Coagulant dose } \\
{[\mathrm{mg} / \mathrm{l} /[\mathrm{ml} / \mathrm{l}]}\end{array}$ & 75 & 0.5 & 0.5 & 0.5 & 0.5 & 0.5 & 0.25 \\
\hline Sludge volume $[\mathrm{ml} / \mathrm{l}]$ & 35 & 20 & 45 & 20 & 20 & 20 & 15 \\
\hline
\end{tabular}

flocks in wastewater. Similar phenomena were observed (but in smaller scale) for Al 3030 and Al 3035.

The low efficiency of agglomerates floating with PAXs caused low efficiency in COD removal. For this reason, the authors resigned from using PAXs chemicals. Also Al 3030 and Al 3035 were rejected from further research. The unstable sludge, generated with those coagulants, rejects their potential application in cosmetics wastewater treatment despite high effectiveness. The sludge generated with $\mathrm{Al}_{2}\left(\mathrm{SO}_{4}\right)_{3}, \mathrm{Al} 3010$ and Al 1019 was stable and hard to break. These coagulants were selected for further research. The results of DAF for samples 2-5 are shown in Table 4.

The DAF experiments for samples 2-5 were done with $\mathrm{Al}_{2}\left(\mathrm{SO}_{4}\right)_{3}, \mathrm{Al} 3010$ and $\mathrm{Al} 1019$. For other aluminum-based coagulants only verification tests were done (data not shown) which confirmed observations from first series. The smallest COD values in treated wastewater were observed in samples 1 and 2 independently from applied coagulant. However, this is the result of much smaller COD concentrations in raw wastewater rather than due to high treatment efficiency.

The highest efficiency of pollutants removal was obtained in samples 3 and 5, 72.9-77.1\% and 68.0-77.7\% respectively (as a COD removal). The high treatment efficiency may be explained due to substantial amount of suspended solids, petroleum ether extractable organics and low amount of easily settleable solids. In the case of these samples, the decrease of COD value was related to the removal of suspended solids but also soluble substances.

Sample 4 was resistant to treatment by DAF. The efficiency of COD removal for all coagulants is lower than $25 \%$ in each case. During this process it was not possible to remove all solids and colloids from wastewater. COD value for treated wastewater was higher than $\mathrm{COD}_{\text {dis }}$ of raw wastewater (573-674 mg/l, respectively, in comparison to $527 \mathrm{mg} / \mathrm{l}$ ).

Due to high variations of wastewater parameters, related to variable wastewater contents and amount of pollutants, it 
Table 4. Dissolved Air Flotation parameters in the samples 2-5

\begin{tabular}{|c|c|c|c|c|}
\hline Sample & & $\mathrm{Al}_{2}\left(\mathrm{SO}_{4}\right)_{3}$ & Al 3010 & Al 1019 \\
\hline \multirow{4}{*}{2} & COD after flotation [mg/l] & 197 & 215 & 179 \\
\hline & COD removal [\%] & 37.3 & 31.5 & 43.0 \\
\hline & Optimal dosage [mg/l] or [ml//] & 75 & 0.5 & 1 \\
\hline & Sludge volume [ml/l] & 20 & 20 & 20 \\
\hline \multirow{4}{*}{3} & COD after flotation [mg/l] & 345 & 409 & 367 \\
\hline & COD removal [\%] & 77.1 & 72.9 & 75.6 \\
\hline & Optimal dosage $[\mathrm{mg} / \mathrm{l}]$ or $[\mathrm{ml} / \mathrm{l}]$ & 125 & 1 & 1 \\
\hline & Sludge volume [ml//] & 90 & 40 & 70 \\
\hline \multirow{4}{*}{4} & COD after flotation [mg/l] & 589 & 674 & 573 \\
\hline & COD removal [\%] & 22.3 & 11.1 & 24.4 \\
\hline & Optimal dosage $[\mathrm{mg} / \mathrm{l}]$ or $[\mathrm{ml} / \mathrm{l}]$ & 100 & 0.5 & 0.5 \\
\hline & Sludge volume $[\mathrm{ml} / \mathrm{l}]$ & 60 & 40 & 40 \\
\hline \multirow{4}{*}{5} & COD after flotation [mg/l] & 680 & 680 & 474 \\
\hline & COD removal [\%] & 68.0 & 68.0 & 77.7 \\
\hline & Optimal dosage [mg/l] or [ml/l] & 125 & 0.5 & 0.5 \\
\hline & Sludge volume [ml//] & 40 & 30 & 30 \\
\hline
\end{tabular}

is impossible to compare our results of 5 samples investigated to the results reported by other authors (Aloui et al. 2009, El-Gohary et al. 2010, Carballa et al. 2007) who only studied one sample (different in the case of composition compared to tested wastewaters). Differentiation of chemical composition and general content of organic pollutants in wastewater results in different susceptibility to chemical treatment.

The agglomerates generated during flocculation process are floated on the surface of the liquid by tiny air bubbles which appear in the liquid by decreasing the pressure. During the flotation process, the decompression of gas which causes generation of small bubbles may bring decomposition of flocks (due to small bubbles trapped in sludge agglomerates).

Desintegration of the flocks structure also occurs at the stage of their elevation. The desintegration is caused by the friction between contact surface of the flock and particles solvent. Type of coagulant is important for the effectiveness of cross-linking flocks with flocculant and durability combined with gas bubbles. The best results were obtained for flotation with use of a coagulant with the highest concentration of $\mathrm{Al}^{3+}$ and a high density.

The secondary flocculation process related to application of a big dose of flocculant is not able to tie all agglomerates. For that reason, the efficiency of secondary flocculation is lower than that of primary flocculation. The additional factor which decreased flotation efficiency was sedimentation of some of agglomerates after time of flotation. The main advantage of using flocculant is acceleration of coagulation and flocs formation. Due to usage of flocculant, the agglomerates were occurring instantly. On the other hand, the shortening of agglomeration time and adsorption time at the agglomerates surface caused higher COD values and lower process efficiency.

The content of aluminum $\left(\mathrm{Al}^{3+}\right)$ ions was determined (spectrometricaly, Hach DR 6000, Chromazurol S method, LCK 301) selectively during preliminary tests and in some optimal samples (the highest COD removal). The aluminum ions concentrations were each time below the industrial wastewater discharge standard (Regulation of the Minister of Environment, Journal of Laws of the Republic of Poland of 18 November 2014 r. item. 1800), prior to their discharge to the sewage system and then biological treatment plant. The obtained results are consistent with research results presented by Gumińska (2013). A small concentration of aluminum ions in the treated wastewater samples occurred only when using the optimal dosage of the reagents and maintaining the proper $\mathrm{pH}$ (close to 7.0).

DAF efficiency was not only connected with COD removal. The additional effect was almost a $100 \%$ removal of color and turbidity. Because the main source of turbidity in cosmetic wastewater is the presence of suspensions (described as e.g. TSS), it can be assumed that the complete removal of turbidity means also the complete removal of suspensions (TSS) and related colloidal compounds the color was removed by precipitation or adsorption rather than coagulation.

\section{HS-SPME-GC-MS analysis}

Compounds identified by HS-SPME-GC-MS method are presented in Table 5. The HS-SPME-GC-MS method refers only to compounds that have significant volatility, large affinity for the material of which the fiber is made and that are resistant to thermal degradation (desorption at high temperature in a chromatograph inlet). A large part of the compounds present in the cosmetic wastewater meets these conditions, therefore it can be assumed that the HS-SPME-GC-MS method can be successfully used for DAF treatment efficiency assessment. Moreover, the advantage of this method is speed and the lack of solvents required. HS-SPME-GC-MS method can be used as a supplement to standard analysis performed in such studies. Among the cosmetic ingredients, a number of compounds are characterized by significant toxicity and other harmful activity (interfering with the endocrine system operation - endocrine disruption). The removal of these compounds from wastewater 
Table 5. Compounds detected in the raw wastewater

\begin{tabular}{|c|c|}
\hline No. & Compound \\
\hline 1 & ally(dimethyl)phenoxysilane \\
\hline 2 & octamethylcyclotetrasiloxane \\
\hline 3 & $(E)$ - 2-nonenal \\
\hline 4 & Eucalyptol (cineole) \\
\hline 5 & 2-methyl-6-methylene-2-octanol (dihydro myrcenol) \\
\hline 6 & 4-undecanol \\
\hline 7 & decamethylcyclopentasiloxane \\
\hline 8 & phenylmethylester acetic acid (acetic acid benzylester) \\
\hline 9 & menthol \\
\hline 10 & 5-Methyldecane \\
\hline 11 & tetrahydro-4-methyl-2-(2-methylpropenyl)-2H-pyran \\
\hline 12 & 2,6,6-trimethylbicyclo[3.1.1]heptane (pinane) \\
\hline 13 & 2-phenoxyethanol \\
\hline 14 & 6-methyl-4-undecene \\
\hline 15 & 3-carene \\
\hline 16 & 9-hydroxy-2,2-dimethyl-dec-5-en-3one \\
\hline 17 & 1,4-dimethyl-cis-cyclooctane \\
\hline 18 & 7,7-dimethyl-2-methylenebicyclo[2.2.1]heptane (7,7-dimethyl-2-methylenenorbornane) \\
\hline 19 & 1,7,7-trimethylbicyclo[2.2.1]hept-2-ylacetate (bornylacetate) \\
\hline 20 & 7-ethenyl-5-undecene \\
\hline 21 & 4-(1,1-dimethylethyl)-cyclohexanone \\
\hline 22 & 4-methyltridecane \\
\hline 23 & 4-tert-butylcyclohexylacetate \\
\hline 24 & dodecamethylcyclohexasiloxane \\
\hline 25 & unknown \\
\hline 26 & 4-methyl-1-(1-methylethyl),acetate-3-cyclohexen-1-ol (p-Menth-1-en-4-ol, acetate, terpinene 4-acetate) \\
\hline 27 & 2,2,4,4,6,8,8-heptamethylnonane \\
\hline 28 & 4-tert-butylcyclohexylacetate \\
\hline 29 & 2,2-dimethyl-3-methylene-,(1R)-bicyclo[2.2.1]heptane \\
\hline 30 & Unknown \\
\hline 31 & diphenylether \\
\hline 32 & 4-tert-butylcyclohexylacetate \\
\hline 33 & $\begin{array}{l}\text { 3-methyl-5-phenyl-1-hexen-4-ol } \\
\text { Indan-1,3-diol monoacetate }\end{array}$ \\
\hline 34 & 4-(2,6,6-trimethyl-2-cyclohexen-1-yl)-3-buten-2-one (iraldeine) \\
\hline 35 & 4-(2,6,6-trimethyl-cyclohexen-1-yl)-2-butenone \\
\hline 36 & 3-(4-isopropylphenyl)-2-methylpropionaldehyde (beta-methyl-p-isopropylhydrocinnamic aldehyde) \\
\hline 37 & 1-tridecanol \\
\hline 38 & bis(2-methylpropyl) ester butanedioic acid (succinic acid diisobutylester) \\
\hline 39 & 3-methyl-4-methylenecyclopentacarboxylic acid methylester \\
\hline 40 & 4-(2,6,6-trimethyl-1-cyclohexen-1-yl)-3-buten-2-one (beta-ionane) \\
\hline 41 & tetradecamethylcycloheptasiloxane \\
\hline 42 & unknown \\
\hline 43 & 5-octadecene \\
\hline 44 & benzoic acid, 2-hydroxy-3-methylbutylester (salicylic acid, isopentylester) \\
\hline
\end{tabular}




\begin{tabular}{|c|c|}
\hline No. & Compound \\
\hline 45 & pentylester 2-hydroxybenzoic acid (salicylic acid pentylester) \\
\hline 46 & 9-(1-methylethylidene)-1,5-cycloundecadiene \\
\hline 47 & 8,8-dimethyl-9-methylene-1,5-cycloundecadiene \\
\hline 48 & 1-cyclohexyl-2-pyrrolidone \\
\hline 49 & methyl p-tert-butylphenylacetate \\
\hline 50 & cedrol \\
\hline 51 & acetic acid 5,5-dimethyl-6-(3-methyl-buta-1,3-dienyl)-7-oxa-bicyclo[4.1.0]hept-1-ylmethyl ester \\
\hline 52 & benzophenone \\
\hline 53 & 1-(2,6,6-trimethyl-1-cyclohexen-1-yl)-1-penten-3-one (methyl-beta-lanone) \\
\hline 54 & methylester 3-oxo-2-pentylcyclopentaneacetic acid (methyldihydrojasmonate) \\
\hline 55 & unknown \\
\hline 56 & unknown \\
\hline 57 & unknown \\
\hline 58 & unknown \\
\hline 59 & unknown \\
\hline 60 & 2,2,4,4,7,7-hexamethyl-2,3,3a,4,7,7a-hexahydro-1H-indene \\
\hline 61 & 3-methyl-4-(2,6,6-trimethyl-1-cyclohexen-1-yl)-3-buten-2-one (iraldeine) \\
\hline 62 & n-hexylsalicylate (hexylester 2-hydroxybenzoic acid) \\
\hline 63 & 2-(phenylmethylene)-octanal (hexylcinnamaldehyde) \\
\hline 64 & unknown \\
\hline 65 & ambrosin \\
\hline 66 & 6-[1-(acetyloxy)-3-oxabutyl]-3,3a,4,7,8,8a-hexahydro-7-methyl-3-methylene-2H-cyclohepta[b]furan-2-one \\
\hline 67 & 1-methylethylester tetradecanoic acid (isopropylmyristate) \\
\hline 68 & methylester 9,12-octadecadienoic acid \\
\hline 69 & (Z,Z)-9,12-octadecadienoic acid \\
\hline 70 & unknown \\
\hline 71 & unknown \\
\hline 72 & 1,3,4,6,7,8-hexahydro-4,6,6,7,8,8-hexamethylcyclopenta[g]-2-benzopyran (galaxolide) \\
\hline 73 & dibutyl phthalate \\
\hline 74 & cyclohexadecane \\
\hline 75 & tonalide \\
\hline 76 & unknown \\
\hline 77 & unknown \\
\hline 78 & unknown \\
\hline 79 & 2-hexyldecanoic acid \\
\hline 80 & dibutyl phthalate \\
\hline 81 & 1-methylbutyl hexadecanoate \\
\hline 82 & 1,4-dioxacycloheptadecane-5,17-dione (ethylene brassylate) \\
\hline 83 & unknown \\
\hline 84 & 1-eicosanol \\
\hline 85 & unknown \\
\hline 86 & benzoic acid undecylester \\
\hline 87 & unknown \\
\hline 88 & unknown \\
\hline 89 & benzoic acid octylester \\
\hline 90 & benzoic acid undecylester \\
\hline
\end{tabular}


should be a high priority. The HS-SPME-GC-MS application allowed the unambiguous confirmation that the use of DAF effectively removes these compounds from wastewater by moving them to the sludge phase.

The efficiency of the DAF process for various coagulants, calculated on the basis of the reduction in the total area under the peaks in the chromatograms was greater than the effectiveness of COD decreasing. The highest process effectiveness, based on HS-SPME-GC-MS analysis, was found for Al 3035 (89.4\%), while the lowest for PAX 16 (55.3\%). Differences in the efficacy of treatment determined by two recognized methods (COD and HS-SPME-GC-MS) were 14.9-28.5\%. This phenomenon results from the fact that the method HS-SPME-GC-MS allows for the analysis of compounds which exhibit volatility, sorbs on the SPME fiber surface and are resistant to thermal decomposition (desorption on chromatograph injector). Impurities in the wastewater sample satisfying these conditions are very effectively eliminated by DAF, by sorption of solutes on the flocs (high affinity for solid phase - hydrophobic properties), removal of suspensions, solutes rinsing gas stream in the form of bubbles released (volatility), removal substances forming an emulsion in raw wastewater (low solubility in the aqueous phase). HS-SPME-GC-MS analysis can be a confirmation of the effectiveness of the DAF in technological research. Moreover, it can form the basis of the assessment of a nuisance.

\section{Conclusions}

The COD value for raw wastewater was in the range 285-2124 mg/l. The efficiency of the DAF method was different depending on coagulant used in the treatment process and profile production of cosmetics factory and varied between $11.1-77.7 \%$ of COD removal. The best results were obtained with usage of the coagulant $\mathrm{Al}_{2}\left(\mathrm{SO}_{4}\right)_{3}$ for sample 5 and the production lotions and shampoos. The wastewater from the production of creams with UV filter (sample 4) was resistant to treatment by DAF method regardless of coagulant used. HS-SPME-GC-MS analysis can be a confirmation of the effectiveness of the DAF in technological research. Moreover, it can form the basis of the assessment of a nuisance.

\section{Acknowledgments}

The authors gratefully acknowledged the financial support provided by National Science Centre (grant no. 7385/B/ T02/2011/40 "Chemical pretreatment of effluents from cosmetic industry").

\section{References}

Aloui, F., Kchaou, S.\& Sayadi, S. (2009). Physicochemical treatments of anionic surfactants wastewater: Effect on aerobic biodegradability, Journal of Hazardous Materials, 164, pp. 353-359.

Bautista, P., Mohedano, A.F., Gilarranz, M.A., Casas, J.\& Rodriguez, J. (2007). Application of Fenton oxidation to cosmetic wastewaters treatment, Journal of Hazardous Materials, 143, pp. 128-134.

Bautista, P., Mohedano, A., Menendez, N., Casas, J. \& Rodriguez, J.J. (2010). Catalytic wet peroxide oxidation of cosmetic wastewaters with Fe-bearing catalysts, Catalysis Today, 151, pp. 148-152.

Bautista, P., Mohedano, A.F., Casas, J.A., Zazo, J.A. \& Rodriguez. J.J. (2010). Oxidation of cosmetic wastewaters with $\mathrm{H}_{2} \mathrm{O}_{2}$ using a Fe/g- $\mathrm{Al}_{2} \mathrm{O}_{3}$ catalyst, Water Science and Technology, 61, pp. 1631-1636.

Boroski, M., Rodrigues, A.C., Garcia, J.C., Sampaio, L.C., Nozaki, J. \& Hioka, N. (2009). Combined electrocoagulation and $\mathrm{TiO}_{2}$ photoassisted treatment applied to wastewater effluents from pharmaceutical and cosmetic industries, Journal of Hazardous Materials, 162, pp. 448-454.

Burek, M. (2008). Report on implemented solutions in the AVON Operations Polska Sp. z o.o. company wastewater treatment plant, Gaz, woda i technika sanitarna, 12, pp. 31-33.

de Melo, E. D., Mounteer, A.H., de Souza Leăo, L.H., Bahia, R.C.B. \& Campos, I.M.F. (2013). Toxicity identification evaluation of cosmetics industry wastewater, Journal of Hazardous Materials, 244-245, pp. 329-334.

Carballa, M., Manterola, G., Larrea, L., Ternes, T., Omil, F. \& Lema, J. (2007). Influence of ozone pre-treatment on sludge anerobic digestion: Removal of pharmaceutical and personal care products, Chemosphere, 67, pp. 1444-1452.

Carpinteyro-Urban, S., Vaca, M. \& Torres, L.G. (2012). Can vegetal biopolymers work as coagulant-flocculant aids in the treatment of high-load cosmetic industrial wastewaters? Water, Air \& Soil Pollution, 223, pp. 4925-4936.

Ebrahiem, E.E., Al-Maghrabi, M.N. \& Mobarki, A.R. (2013). Removal of organic pollutants from industrial wastewater by applying photo-Fenton oxidation technology, Arabian Journal of Chemistry, doi:10.1016/j.arabjc.2013.06.012.

El-Gohary, F., Tawfik, A. \& Mahmoud, U. (2010). Comparative study between chemical coagulation/precipitation $(\mathrm{C} / \mathrm{P})$ versus coagulation/dissolved air flotation (C/DAF) for pre-treatment of personal care products (PCPs) wastewater, Desalination, 252, pp. 106-112.

Friha, I., Karray, F., Feki, F., Jlaiel, L. \& Sayadi, S. (2014). Treatment of cosmetic industry wastewater by submerged membrane bioreactor with consideration of microbial community dynamics, International Biodeterioration \& Biodegradation, 88, pp. 125-133.

Friha, I., Feki, F., Karray, F. \& Sayadi, S. (2012). A pilot study for cosmetic wastewater using a submerged flat sheet membrane bioreactor, Procedia Engineering, 44, pp. 819-820.

Gumińska, J. (2013). Modification of conventional coagulation system by application of post-coagulation sludge recirculation, Ochrona Środowiska, 35 (3), pp. 17-22.

Marcinowski, P., Bogacki, J. \& Naumczyk, J. (2014). Cosmetic wastewater treatment using the Fenton, Photo-Fenton and $\mathrm{H}_{2} \mathrm{O}_{2} / \mathrm{UV}$ processes, Journal of Environmental Science and Health, Part A, 49, pp. 1531-1541.

Monsalvo, V.M., Lopez, J., Mohedano, A.F. \& Rodrigues, J.J. (2014). Treatment of cosmetic wastewater by a full-scale membrane bioreactor, Environmental Science and Pollution Research, 21, pp. 12662-12670.

Naumczyk, J., Marcinowski, P., Bogacki, J. \& Wiliński, P. (2013). Cosmetic wastewater treatment by coagulation, Rocznik Ochrona Środowiska, 15, pp. 875-891.

Naumczyk, J., Bogacki, J., Marcinowski, P. \& Kowalik, P. (2014). Cosmetic wastewater treatment by coagulation and advanced oxidation processes, Environmental Technology, 35, pp. 541-548.

Perdigon-Melon, J., Carbajo, J., Petre, A., Rosal, R. \& Garcia-Calvo, E. (2010). Coagulation-Fenton coupled treatment for ecotoxicity reduction in highly polluted industrial wastewater, Journal of Hazardous Materials, 181, pp. 127-132.

Puyol, D., Monsalvo, V.M., Mohedano, A.F., Sanz, J.L. \& Rodriguez, J.J. (2011). Cosmetic wastewater treatment by upflow anaerobic sludge blanket reactor, Journal of Hazardous Materials, 185, pp. 1059-1065.

Rozporządzenie Ministra Środowiska, Dziennik Ustaw z dnia 18 listopada 2014 r. Poz. 1800, w sprawie warunków, jakie należy spełnić przy wprowadzaniu ścieków do wód lub do ziemi, oraz 
w sprawie substancji szczególnie szkodliwych dla środowiska wodnego.

Vlyssides, A.G., Mai, S.Th., Barampouti, E.M.P. \& Loukakis, H.N. (2009). Influence of vegetation and gravel mesh on the tertiary treatment of wastewater from a cosmetics industry, Journal of Environmental Science and Health, Part A, 44, pp. 820-826.

Wang, L.K., Shammas, N.K., Selke, W.A. \& Aulenbach, D.B. (2010). Handbook of environmental engineering, volume 12, "Flotation Technology", Humana Press (Humana Press is part of Springer Science + Business Media), New York.
Wang, X.-J., Song, Y. \& Mai, J.-S. (2008). Combined Fenton oxidation and aerobic biological processes for treating a surfactant wastewater containing abundant sulfate, Journal of Hazardous Materials, 160, pp. 344-348.

www.brenntag.pl (accessed on 03. 02. 2012). Brenntag. www.kemipol.com (accessed on 03. 02. 2012). Kemipol.

Zhang, C., Ning, K., Guo, Y., Chen, J., Liang, C., Zhang, X., Wang, R. \& Guo, L. (2013). Cosmetic wastewater treatment by a combined anaerobic/aerobic (ABR+UBAF) biological system, Desalination and Water Treatment, 1, pp. 1-7.

\section{Oczyszczenie ścieków kosmetycznych z wykorzystaniem procesu flotacji ciśnieniowej}

Streszczenie: Pięć próbek ścieków kosmetycznych zostało poddanych oczyszczaniu z wykorzystaniem flotacji ciśnieniowej wspomaganej koagulacją. Stosowano różne koagulanty na bazie glinu: $\mathrm{Al}_{2}\left(\mathrm{SO}_{4}\right)_{3}, \mathrm{Al} 1019, \mathrm{Al} 3010$, Al 3030, Al 3035, PAX 16 and PAX 19. Wartość ChZT ścieków surowych była w zakresie 285-2124 mg/l. Skuteczność procesu flotacji ciśnieniowej była zależna od zastosowanego koagulantu i profilu produkcji fabryki kosmetyków. Skuteczność usunięcia wartości ChZT była w przedziale 11,1-77,7\%. Skuteczność wszystkich koagulantów podczas oczyszczania każdej z próbek ścieków była podobna. Najlepsze rezultaty uzyskano z wykorzystaniem koagulantu $\mathrm{Al}_{2}\left(\mathrm{SO}_{4}\right)_{3}$, dla próbki 5 - ścieki pochodzące z produkcji szamponów i logionów. Ścieki z produkcji kremów z filtrem UV (próbka 4) były oporne na oczyszczanie za pomocą procesu flotacji ciśnieniowej, niezależnie od zastosowanego koagulantu. Zastosowana analiza HS-SPME-GC-MS potwierdziła skuteczność oczyszczania z wykorzystaniem flotacji ciśnieniowej. 